\title{
Fatally entangled right whales can die extremely slowly
}

\author{
Michael J. Moore ${ }^{1}$, Andrea Bogomolni ${ }^{1}$, Robert Bowman ${ }^{2}$, Philip K. Hamilton ${ }^{3}$, Charles T. \\ Harry $^{4}$, Amy R. Knowlton ${ }^{3}$, Scott Landry ${ }^{2}$, David S. Rotstein ${ }^{5}$, and Kathleen Touhey ${ }^{4}$ \\ (1) Woods Hole Oceanographic Institution, Mailstop 50, Woods Hole, MA 02543, USA \\ (2) Provincetown Center for Coastal Studies, Box 1036, Provincetown, MA 02567, USA \\ (3) New England Aquarium, Central Wharf, Boston, MA 02110, USA \\ (4) Cape Cod Stranding Network, PO Box 287, Buzzards Bay, MA 02532, USA \\ (5) University of Tennessee, 247 River Drive, Room A201, Knoxville, TN 37996, USA
}

\begin{abstract}
Unlike smaller marine mammals that lack the mass and power to break free from serious entanglements in fixed fishing gear, right whales can do so, but they are not always rope free. The remaining rope can gradually constrict one or more body parts and the resulting debilitation and ultimate death can take many months. Thus the practices that lead to these mortalities need to be viewed not only as a conflict between the cultural and socioeconomic value of a fishery versus a potential species extinction process, but also in terms of an extreme animal welfare issue.
\end{abstract}

\section{INTRODUCTION}

Between 1986 and June 2005 6/66 North Atlantic right whales reported to be entangled in fishing gear died. 35/66 were disentangled or shed gear on their own. Death is presumed, given no sightings for 6 consecutive years, in at least 5 more cases. Death is suspected in 12 further cases, because of disappearance and/or the extremely poor health condition observed at the time of last sighting. 8 animals were still entangled; their fate uncertain [1]. Overall, 75\% of North Atlantic right whales show entanglement scars. It has been estimated that 49 to 136 get entangled annually, thus most self disentangle [2] and go unreported.

\section{METHODS AND RESULTS}

At least 12 cases were believed (as of 06/2005) to continue carrying potentially life- threatening entanglements. Of 17 entanglements not

Supported by NOAA NA04NMF4720392, Woods Hole Oceanographic Institution Ocean Life Institute, and the North Pond Foundation.

passively shed between 1999 and 2005, the average duration was at least 10 months. Of those that died, the average time to death was 5.6 months (Table 1). It appears that some cases that debilitate very slowly, burn lipids to the point that they sink at death and thus go unrecorded resulting in an underestimate of the overall impact.

Entanglements involve one or more of the rostrum, baleen, flipper(s) and peduncle. If the gear is anchored to the bottom, has a heavy weight hanging off the animal or is fixed in more than one place on the body, as the animal flexes

Table 1: Summary of entanglement mortality cases

\begin{tabular}{|c|c|c|c|}
\hline Case & Months & Body part(s) & Major pathology \\
\hline 2366 & 11.7 & $\begin{array}{l}\text { Baleen and } \\
\text { right flipper }\end{array}$ & $\begin{array}{l}\text { Line encircling } \\
\text { radius cut in to } \\
\text { bone (Figure 1a) }\end{array}$ \\
\hline 2030 & 6.5 & Both flippers & $\begin{array}{l}\text { Line between } \\
\text { flippers dissected } \\
\text { off a broad sheet } \\
\text { of dorsal blubber }\end{array}$ \\
\hline 1102 & 4.3 & Rostrum & $\begin{array}{l}\text { Died and sank at } \\
\text { sea - not } \\
\text { examined post } \\
\text { mortem }\end{array}$ \\
\hline 3107 & 4.2 & Peduncle & $\begin{array}{l}\text { Line incised soft } \\
\text { tissue to ventral } \\
\text { tendons, } \\
\text { lacerating two } \\
\text { large veins }\end{array}$ \\
\hline 1238 & 0 & $\begin{array}{l}\text { Baleen, right } \\
\text { flipper and } \\
\text { peduncle }\end{array}$ & $\begin{array}{l}\text { Rope impressions } \\
\text { but no internal } \\
\text { damage - assume } \\
\text { died at depth in } \\
\text { trawl }\end{array}$ \\
\hline 2301 & 6.9 & $\begin{array}{l}\text { Baleen, } \\
\text { blowhole and } \\
\text { left flipper }\end{array}$ & $\begin{array}{l}\text { Major laceration } \\
\text { in flipper with } \\
\text { prolific periosteal } \\
\text { bone proliferation } \\
\text { (Figure } 1 \mathrm{~b} \text { ) }\end{array}$ \\
\hline \multicolumn{4}{|c|}{$\begin{array}{l}\text { Figure } 1 \text { - Chronic entanglement impacts on North Atlantic } \\
\text { right whales. } \\
\text { a. Dorsal view of rostrum of case } 2301 \text { showing furrow } \\
\text { induced by chronic rope pressure over left nostril (L). Right } \\
\text { nostril is unaffected (R) } \\
\text { b. Medial view of right radius of case } 2366 \text { showing } \\
\text { notch where radius grew around entangling lines. }\end{array}$} \\
\hline
\end{tabular}



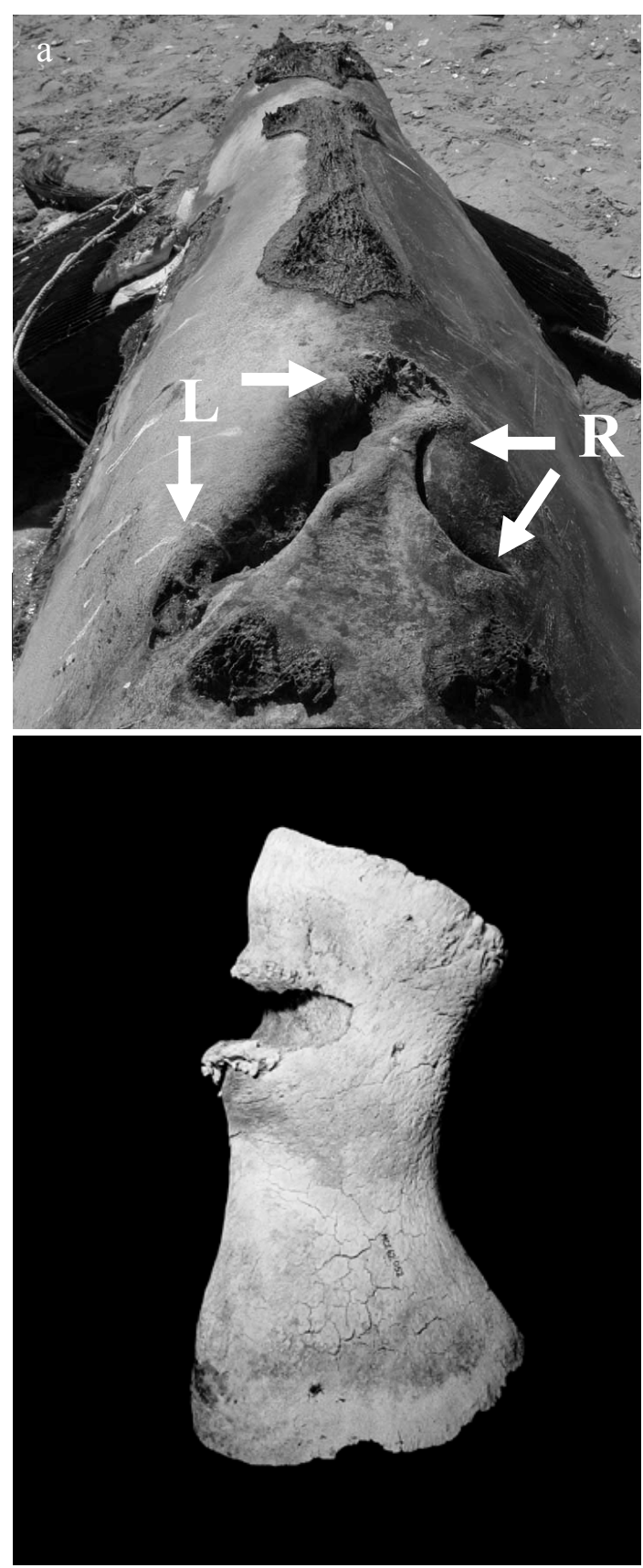

to swim, the wraps of gear cinch increasingly tighter. This results in major progressive constriction and tissue damage (Figure 1a). Histologically, constrictions are walled off with fibrosis and may include woven bone proliferating from the periosteum of underlying bones. Immobilization of a flipper has in two cases lead to disuse osteoporosis. Inflammation is absent to a remarkable degree. Computer tomographs of a chronically entangled flipper show a sequestered wedge of necrotic bone in the radius. In one growing whale the gear was tightly wrapped around both flippers and across the back so that part of the dorsal blubber coat was peeled back by the incising rope. In another growing whale the radius bone in the flipper grew such that it was notched by encircling rope (Figure 1b). In another case a simple loop of line cut in to the peduncle, lacerating two superficial veins [3].

\section{DISCUSSION}

These cases represent one of the grossest abuses of wild animal sensibility in the modern world. Activity in the US courts system has focused on the impacts of such mortalities on the potential survival of the North Atlantic right whale species. Such concerns are indeed valid $[4,5]$. However, there is in parallel a major violation of the welfare of individual animals. Modern technology to harvest a whale results in a far, far more acceptable time from impact to death: minutes if not seconds [6]. In contrast the process of dying over periods of months or being continuously entangled for in one case over four years, seems to be barbaric in the extreme.

Current measures to enhance the weakness of fixed gear to avoid anchoring entangled animals may reduce but will not remove the risk of progressive, constrictive rope damage. There needs to be a combination of measures that reduce or eliminate line and/or make line that will not lead to serious injury. A significant change must involve a modernization of fixed gear fisheries to enhance their efficiency and hence substantially reduce the amount of rope in the water column in right and other large whale habitat.

\section{REFERENCES}

[1] S. Kraus, M. Brown, H. Caswell, C. Clark, M. Fujiwara, P. Hamilton, R. Kenney, A. Knowlton, S. Landry, C. Mayo, W. McLellan, M. Moore, D. Nowacek, D. Pabst, A. Read, and R. Rolland, "North Atlantic Right Whales in Crisis," Science, vol. 309, pp. 561-2, 2005.

[2] A. Johnson, G. Salvador, J. Kenney, J. Robbins, S. D. Kraus, S. Landry, and P. Clapham, "Fishing Gear Involved in Entanglements of Right and Humpback Whales," Marine Mammal Science, vol. 21, pp. 634-645, 2005.

[3] M. Moore, A. Knowlton, S. Kraus, W. McLellan, and R. Bonde, "Morphometry, gross morphology and available histopathology in Northwest Atlantic right whale (Eubalaena glacialis) mortalities (1970 to 2002)," Journal Cetacean Research and Management, vol. 6, pp. 199-214, 2005.

[4] H. Caswell, M. Fujiwara, and S. Brault, "Declining survival probability threatens the North Atlantic right whale," Proceedings of the National Academy of Sciences, vol. 96, pp. 33083313, 1999. 
[5] M. Fujiwara and H. Caswell, "Demography of the endangered North Atlantic right whale," Nature, vol. 414, pp. 537-541, 2001.

[6] IWC, "Report of the workshop on whale killing methods and associated welfare issues,"
Cambridge, UK International Whaling Commission IWC/55/Rep 5, 2003. 